\title{
From Wesleyanism To Pentecostalism: Historical And Theological Perspectives
}

\section{Isaac Boaheng ${ }^{1}$}

${ }^{1}$ Translator - Bible Society of Ghana

\begin{abstract}
Undoubtedly, Pentecostalism is the most influential religious movement of the twentieth century. Not only has this movement changed the religious landscape of the world, but it has also contribut-ed enormously to the growth of Christianity in many societies. The contributors to the rapid growth of Pentecostal churches as compared to mainline historic churches have attracted scholarly atten-tion for some time now. Current theological interest in this subject has prompted this study that traces the success of Pentecostalism to its adherence to foundations laid by the Wesleyan Holiness revival movement of the nineteenth century. Through a historico-theological survey, the author contends that Wesleyan teachings and practices such as the authority of the Bible, holiness, use of spiritual gifts, evangelism, social ministry, and others, are key to the survival of global Christianity now and in the years to come.
\end{abstract}

Correspondence: Isaac Boaheng

Email: revisaacboaheng@ gmail.com

Manuscript

Received 26th June 2020,

Accepted 12th August 2020,

Published online 17th August 2020.

Keywords: Holiness, Methodism, Renewal, Pentecostalism, Holy Spirit baptism, speaking in tongues.

\section{INTRODUCTION}

John Wesley ${ }^{2}$, the fifteenth child to Rev. Samuel Wesley, an Anglican priest and Mrs. Susana Wesley, was born on June 17,1703 , as "the fruit of reconciliation", after his parents experienced a stormy period in their marriage due to their disagreement over the legitimate monarch of England. ${ }^{3}$ His upbringing took place at the Epworth rectory, where his mother's influence became very strong. ${ }^{4}$ On Thursday, February 9, 1709, Wesley was miraculously rescued from fire outbreak at the Epworth Rectory, an incident which Wesley later interpreted as "a sign of God's sparing his life to save others from eternal damnation." 5

Wesley studied in London and Oxford, living the studious, methodical, and religious life in which he had been trained at home. ${ }^{6}$ He proved himself a man of high morality and was not affected negatively by the moral decay of his school environment. He was commissioned as a deacon on September 19, 1725 (by the Anglican Bishop of Oxford, John Potter and ordained) and ordained in 1728 as an Anglican priest. ${ }^{7}$ Later, Wesley left Oxford and while he was away, his brother, Charles Wesley and two other students (Robert Kirkham and William Morgan) came together to form a small group, which, though was primarily meant to improve their studies, soon turned into a religious group. ${ }^{8}$ The group met frequently to study the Bible, pray, celebrate the Eucharist and embarked on community evangelism and visitation. Later (in 1729), when John Wesley returned to Oxford to teach, he joined his brother's group and was made the leader of the

\footnotetext{
2 Subsequently, John Wesley is referred to as Wesley and, except the first mention, Charles Wesley is referred to as Charles, unless the names of these two brothers are stated in full.

Paul K. Boafo, John Wesley's Theology and Public Life: His Socio-Political Thought in the Ghanaian Context (Accra: Asempa Publishers, 2014$), 1$.

Robert Aboagye-Mensah, John Wesley and the Methodists (Accra: Asempa Publishers, 2013), 11.

Boafo, John Wesley's Theology and Public Life, 17.

Ibid.

Isaac Hopper, "Christ Alone for Salvation”:The Role of Christ and His Work in John Wesley's Theology (PhD Thesis: The University of Manchester, 2017 ), 49-50.

8 Aboagye-Mensah, John Wesley and the Methodists, 20
} 
group because of his leadership qualities and experience. Not long after that, the group attracted a large following and was nicknamed "The Holy Club" because of their strong emphasis on holy living. 9 " After some time, the name of the group was changed to "The Methodists" because members lived by a strict method and organized their things methodically.

In the fall of 1735, Wesley received an invitation from Reverend John Burton to undertake missionary work in the American colony of Georgia. ${ }^{10} \mathrm{He}$ embarked on the journey with three other Methodists, Charles Wesley, Benjamin Ingham and Charles Delamotte. On their way, the Methodists encountered some Moravian missionaries whose "humility, zealous devotion, a strict sense of Christian discipline, mutual accountability, communitarian spirit, and skill at harmoniously singing hymns" got them fascinated. ${ }^{11}$ This is the testimony Wesley gave about the calmness of the Moravians in the face of a great storm that came their way: "A terrible screaming began among the English. The Germans calmly sang on. I asked one of them afterward, 'Was you not afraid?' He answered, 'I thank God, no.' I asked, 'But were not your women and children afraid?' He replied, mildly, 'No; our women and children are not afraid to die'". ${ }^{12}$ This experience sent a signal to Wesley to question the genuineness of his faith in Christ. Wesley's interaction with the Moravian bishop, August Spangenberg, in Georgia gave him a better understanding of the evangelical view of personal salvation and created a state of spiritual unrest within his heart.

Consequently, after returning to England, Wesley decided not to preach again until he acquired the saving faith he now yearned for. However, he met Perter Böhler, a Moravian missionary, who encouraged him to go on preaching until such a time that he has that faith. ${ }^{13}$ Accordingly, on Monday, 6th March 1738, Wesley started preaching this new kind of faith, though his heart was not completely in it. He had other encounters with Böhler which together contributed to his understating of the Christian faith and his search for an experience of God's saving faith. Wesley continued to seek this kind of faith until he experienced it on May 24, 1738, in what has become known as "the strange warmth experience" which happened when he attended a Moravian meeting on the evening of Wednesday, May 24, 1738, on Aldersgate Street. In the evening Wesley reluctantly went to a society in Aldersgate Street where the Moravians had a meeting. At the meeting, a portion of Luther's preface to the Epistle to the Romans was read and upon hearing it Wesley had his most outstanding religious experience. This is what Wesley recorded about it:

In the evening I went very unwillingly to a society in Aldersgate Street, where one was reading Luther's preface to the Epistle to the Romans. About a quarter before nine, while the leader was describing the change which God works in the heart through faith in Christ, I felt my heart strangely warmed. I felt I did trust in Christ alone for salvation; and an assurance was given me that He had taken away my sins, even mine, and saved me from the law of sin and death. ${ }^{14}$

Aboagye-Mensah identifies two scholarly interpretations of this experience. ${ }^{15}$ The first view is that the Aldersgate Street experience marked Wesley's conversion experience, while the other position holds that Wesley experienced the baptism of the Holy Spirit, after an earlier conversion experience. Though no position is conclusive one can be sure that this experience changed Wesley's life entirely and gave him the assurance of salvation.

\section{Historical Roots of Pentecostalism}

By the time of Wesley's death, Methodism had been planted not only in England but also in America. Methodism grew rapidly in America such that by 1850, it was already the largest Christian movement in the country. ${ }^{16}$ From America and England, Methodism with its emphasis on holiness spread to other parts of the world under the auspices of missionaries and traveling evangelists of Methodist persuasion. The early Methodists believed that "creedal rigidity, liturgical strictness, and ironclad institutionalism that had depersonalized religion had rendered it incapable of serving the needs of the individual believer." ${ }^{\prime 7}$ They sought personal salvation and experience of the Holy Spirit, leading to sanctification.

Later, when Methodism became standardized some of its members felt that the movement had become staid and restricting and so some disenchanted Methodists came together to form the Holiness movement to restore some of the enthusiasm of early Methodism..$^{18}$ The Holiness movement organized a camp meeting in Vineland, New Jersey on July 17, 1867 and this effort was replicated in many parts of America. These camp meetings were characterized by aggressive

\footnotetext{
9 Hopper, "Christ Alone for Salvation", 37.

10 Ibid.

11 Geordan Hammond, John Wesley in America: Restoring Primitive Christianity (Oxford: Oxford University Press, 2014), 83

12 John Greenfield, Power from on High: The 20th Anniversary of the Great Moravian Revival 1727-1927 (Atlanta, GA: CTM Publishing, Inc., 2017$), 47$.

13 Hopper, "Christ Alone for Salvation", 66.

14 John Wesley and Charles Wesley, John and Charles Wesley: Selected Prayers, Hymns, Journal Notes, Sermons, Letters, and Treatises edited by Frank Whaling (New York: Paulist Press, 1981), 20

15 Aboagye-Mensah, John Wesley and the Methodists, 45.

${ }_{16}$ Peter Kuzmic, "Pentecostals in the Evangelical Family: A Historical and Theological Reflection" in Together in One Mission: Pentecostal Cooperation in World Evangelization edited by Arto Hamalainen and Grant McClung (Cleveland: Pathway Press, 2012), 45

17 Synan as cited in Elaine J. Lawless, God's Peculiar People: Women's Voices \& Folk Tradition in a Pentecostal Church (Kentucky: The University Press of Kentucky, 2005), 26.

18 Ibid.,26.
} 
evangelism. According to Lawless these holiness movement adhered strictly to Wesley's prohibition of "all alcoholic drinking, dancing, theater-going, card-playing, and swearing, and his restrictions on women's dress were embraced fully and further elaborated by holiness groups to prohibit, in time, Coca-Cola, chewing gum, rings, bracelets, earbobs, and neckties." ${ }^{19}$ Holiness teachings such as "the seeking of a blessing, which ought to be received after and distinct from conversion; a submission to the Spirit in all affairs of life; a lifetime effort to win converts and rejuvenate the spiritual lives of the faithful; a vibrant hope in the imminent return of Christ; and abandonment of the world and all manifestations of 'worldliness"' were to become key doctrines in Pentecostalism. ${ }^{20}$ Many Christian denominations emerged from the Holiness movement of which the Church of Nazarene and the Pilgrim Holiness Church were very prominent.

One of Wesley's students John Fletcher, in 1894 started a movement in Iowa (called The Fire-Baptized Holiness Church) which preached that there is a "third blessing", that is, "the baptism of the Holy Spirit and fire" (or simply "The Fire") which followed and complemented the conversion and sanctification experiences taught by the Methodist Holiness movement. ${ }^{21}$ As the study reveals later, Fletcher differed slightly from Wesley regarding the actual time the one receives the Holy Spirit. Fletcher had a series of revivals in the Midwest that were characterized by the emotional fervor of the early Methodists; at these meetings, people who received the fire would "shout, scream, speak in tongues, fall into trances, and even get the jerks." ${ }^{22}$ Even though both the Holy Spirit baptism and speaking in tongues occurred at the camp meetings, Fletcher's movement made no connection between then at this time and there was no teaching that "this baptism and/or tongue-speaking were necessary prerequisites to salvation."23

Historically, the advent of global Pentecostalism has been regarded as originating from the experiences of Charles Fox Parham (1873-1929) in Topeka and of William J. Seymour (1870-1922) at Azusa Street at the beginning of the twentieth century. Parham, a former Methodist minister, started the Bethel Bible College in Topeka, Kansas in 1900 where many students experienced the baptism of the Holy Spirit and the gift of speaking in tongues..$^{24}$ In 1901 Parham tasked his students to answer the question "What is the Bible evidence of the Baptism of the Holy Ghost?" After several days, the students answered (based on Acts 2:1-4) that the evidence for the Holy Spirit baptism is the speaking in tongues. They also concluded that the Holy Spirit baptism was meant to empower believers for evangelism. This discovery generated in the students the quest to have the same experience as the Apostles had on the day of Pentecost. Parham prayed for one of his students Agnes N. Ozman (1870-1937) and she became the first person to experience the Holy Spirit baptism with speaking in tongues, and hence the first Pentecostal in modern history. Through prayers, many of the students experienced Holy Spirit baptism and then spoke in tongues. Parham spoke tongues himself and also taught that tongues speaking is the initial evidence of the Holy Spirit baptism. ${ }^{25}$ Parham and his students saw what happened as a replica of what happened on the day of Pentecost and so they decided to brand themselves as "Pentecostals."

This was not the first time that the Church was experiencing the speaking of tongues. For example, this phenomenon occurred in the 1830s during the ministration of Presbyterian minister Edward Irving in London as well as in the services of the Shaker movement of Mother Anne Lee in England. By late 1890, the third experience of Holy Spirit baptism and/or speaking in tongues was common in the Holiness churches and camp meetings ${ }^{26}$ However, it was in Topeka, under the leadership of Parham, that the theological link between Holy Spirit baptism as an enduement of power and the accompanying sign of speaking in tongues was established. ${ }^{27}$

The Pentecostal experience at Topeka spread to other parts of the country such as Houston, Texas. In 1906 Pentecostalism took root in Los Angeles where the outpouring of "Latter rains" occurred in a dilapidated African Episcopal Methodist church on the Azusa Street under the leadership of William J. Seymour, ${ }^{28}$ the one-eyed 34-year-old son of freed slaves who was Parham's student and a black holiness preacher from Houston, Texas. The church was opened to all those willing to experience the power of the Holy Spirit. From this time the Azusa Street in Los Angeles became a sort of "American Jerusalem" as numerous Pentecostals around the world came to be filled. "Pentecost has come to Los Angeles, the American Jerusalem. Every sect, creed, and doctrine under Heaven is found in Los Angeles, as well as every nation, [...] sent of God for 'Pentecost' ... Surely we are in the days of the restoration, the 'last days', wonderful days, glorious days." ${ }^{29}$ Many leaders of the Holiness movement came to Los Angeles to have the Pentecostal experience and through this, several Holiness groups were swept into the emerging Pentecostal movement.

\footnotetext{
19 Ibid., 17.

20 Ibid., 27.

21 V. Synan, "Pentecostalism" in Evangelical Dictionary of Theology Second edition edited by Walter A. Elwell (Grand Rapids, MI: Baker Academic, 2001$)$, 900.

2 Lawless, God's Peculiar People, 28.

3 Ibid.,29.

4 Cephas N. Omenyo, Pentecost Outside Pentecostalism (Zoetmeter: Boekencenbtrum Publishing House, 2002 ), 88.

25 Ibid.

William W. Menzies and Robert P. Menzies, Spirit and Power: Foundations of Pentecostal Experience (Grand Rapids, MI: Zondervan, 2000$), 16$.

Ibid.

Synan, "Pentecostalism", 899.

Bartleman, as cited by R. G. Robins, Pentecostalism in America (California: Praeger, 2010), 31.
} 
From Topeka and Los Angeles experiences Pentecostalism spread to other parts of America and the globe with a message that emphasizes salvation and justification by faith, divine healing, premillennial return of Christ, Holy Spirit baptism with the initial sign being the speaking of tongues. Pentecostal Christianity is characterized by a strong emphasis on salvation as a life-changing experience produced by the Holy Spirit and places a high value on pneumatic phenomena (such as "speaking in tongues', prophecies, visions, healing and miracles in general") which believers must consciously and earnestly seek as these phenomena are indications of God's enabling presence among his people. ${ }^{30}$

Interestingly, though Pentecostalism emerged from the Holiness movement, most leaders of the Holiness movement did not accept it. ${ }^{31}$ One such leader is Alma White who described Pentecostals as demon-possessed and mentally unstable. ${ }^{32}$ In addition, many of the oldest Holiness Christian denominations such as the Church of Nazarene, the Wesleyan Methodist Church, the Church of God and The Salvation Army rejected Pentecostal teachings absolutely. ${ }^{33}$ This opposition to pneumatic experiences is reminisced in Asamoah-Gyadu's account of a Methodist catechist, William Egyanka Appiah, who was dismissed in the 1920s for speaking in tongues and facilitating the healing of the sick. ${ }^{34}$ His superintended minister, according to Asamoah-Gyadu, accused him of being an occultist due to the manifestation of pneumatological phenomena in his (Egyanka's) ministry. ${ }^{35}$ The Nazarene Church which initially included the word "Pentecostal" in its name, now dropped the word "Pentecostal" as a way of publicly disassociating itself from the Pentecostals whom it felt placed so much emphasis on emotional experiences and tongue-speaking that they neglected the doctrine of sanctification. ${ }^{36}$ On the contrary, younger and more radical Holiness movements accommodated Pentecostalism and got Pentecostalized.

Nonetheless, many Methodists pioneered the spread of Pentecostalism across the globe. Thomas Ball Barratt, for example, was a Norwegian Methodist minister who established Pentecostal churches in Norway, Sweden, and England. ${ }^{37}$ The Chilean version of Pentecostalism was established by an American Methodist minister, Willis C. Hoover, who was rejected by the Methodist church due to his acceptance of Pentecostal manifestations. ${ }^{38}$ In Korea, the planting of Pentecostalism was facilitated by indigenous revivals with the Methodist and Presbyterian churches in 1906 and $1907 .{ }^{39}$ The foregoing discussions support the assertion that "Methodism is the most important of the modern traditions for the student of Pentecostal origins to understand" because "eighteenth-century Methodism is the mother of the nineteenthcentury American holiness movement which, in turn, bore twentieth-century Pentecostalism." 40

\section{Theological Roots of Pentecostalism}

The previous section outlined how Pentecostalism emerged from the Holiness movements which was developed out of Methodism. The focus of the present section is to outline key theological positions of Methodism that were transferred into the Holiness movement and eventually into Pentecostalism.

\section{Emphasis on the authority of the Bible}

Wesleyanism highlights the priority and finality of the authority of Scripture in Christian beliefs and practices. The idea of Scripture alone (sola Scriptura) was first formulated and propagated by Great Reformers such as Martin Luther, John Calvin and Ulrich Zwingli. ${ }^{41}$ Yet, Wesley's contribution to the development of this doctrine in his time when the church lacked biblical teachings is outstanding. Wesley argued that the Bible is God's self-revelation which is sufficient for human salvation; therefore, whoever studies it diligently and applies it appropriately will sit well with God. His emphasis on the authority of the Bible earned him the accolade the "man of one book", the Bible. He once declared, "I allow no other rule, whether of faith or practice than the Holy Scriptures." ${ }^{\text {"2 }}$ Elsewhere he advised others, "be not wise above what is written. Enjoin nothing that the Bible does not clearly enjoin. Forbid nothing that it does not clearly forbid." 43 To ensure grassroots participation of the study of Scripture, Wesley established the class system where a small number of people came together to study the Bible.

The American Holiness movement that emerged from Methodism maintained the idea of the priority of Scripture

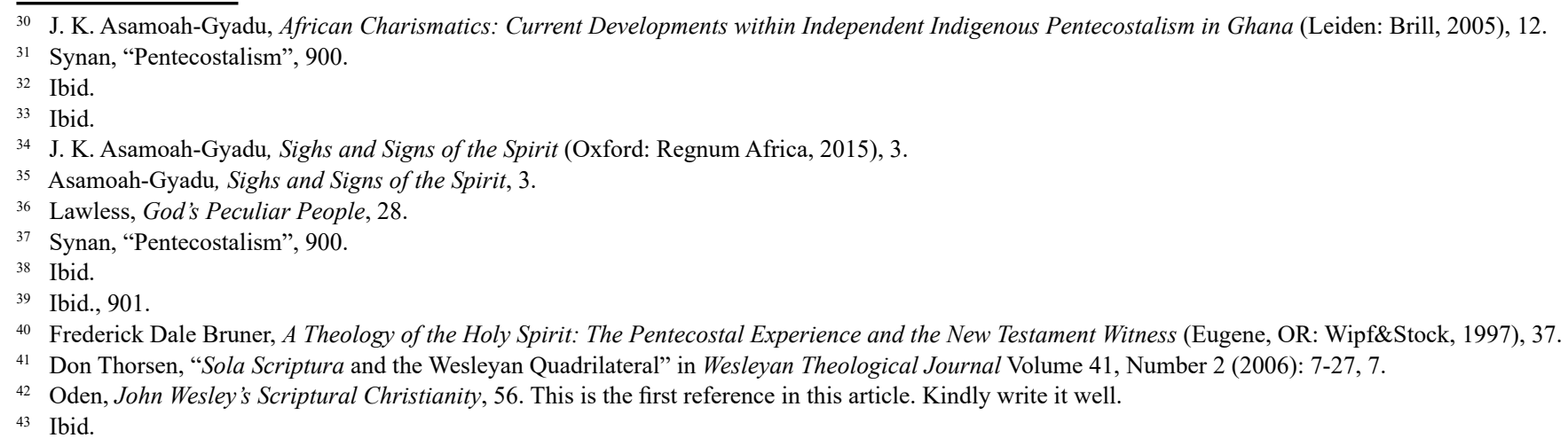


in the theological and ethical formulation and incorporated it into Pentecostal Christianity. The description of Pentecostal churches as "Bible-believing churches" underlines their strong emphasis on the Bible. According to Asamoah-Gyadu, Pentecostals labelled themselves "Bible-believing churches" in order to "define contemporary Pentecostals against their historic mission forebears, who were perceived as either neglecting biblical teachings or diluting the biblical messages to suit the liberal lifestyles of their members and their indifference to such truths as the experiences of the Holy Spirit." ${ }^{44}$ Also, names of Ghanaian Pentecostal churches-including, International Central Gospel Church, Word Miracle Church International, Victory Bible Church-show their emphasis on the Bible in their Christian faith and practice. ${ }^{45}$ Through this emphasis on the Bible, Pentecostals encourage and equip the ordinary Christian to access God's word.

\section{Emphasis on Spiritual Renewal and Holiness}

The eighteenth-century British society in which Wesley ministered, lacked personal piety, the holiness of heart and life, and genuine Christian profession. There was general moral and religious decay that was opposed by pockets of people who eventually formed renewal groups and societies aimed at inspiring Christian spirituality and piety. Wesley responded to this situation by preaching and practising Christian holiness and perfection, throughout his ministry and life. In his teaching about holiness, Wesley compared the structure of the Christian faith to a house (representing holiness of heart and life), which has repentance as its porch and justification by faith (pardon, forgiveness, reconciliation with God) as its door. ${ }^{46}$ Therefore, in Wesleyan's life and thought, to be a Christian is to be holy. The priority that early Methodists gave to holiness earned them the name "Holy Club" (as noted earlier).

Wesley's theology of holiness has two inseparable dimensions, namely, inward or personal holiness and outward or social holiness. ${ }^{47}$ Inward holiness involves "total commitment to God, singleness of intention, centering one's life completely on God", includes "believing in, trusting, worshipping, initiating, and obeying God" and consists of "constant reliance on God's grace and using the gifts God gives to become what he intends us to be." ${ }^{48}$ This requires a constant examination of one's life, repenting of one's sins, and cultivating spiritual gifts. Wesley's theology of purity in heart and life (or sanctification) differs from justification in that the former is a life-long process while the latter happens instantaneously when a sinner receives pardon from God through his or her faith in the atoning sacrifice of Christ. The gradual process of sanctification is to lead to what Wesley termed as Christian Perfection or Entire Sanctification. Wesley's emphasis on Christian Perfection as the goal of the Christian life (Matt. 5:48; 1 John 4:18) distinguishes his theology of holiness from that of other theologians. ${ }^{49}$ By Christian Perfection, Wesley does not mean freedom from ignorance, mistakes, and temptation but rather that with the help of God the believer can have a pure heart and the greatest gift of the Spirit by which love becomes the controlling affection of one's life so that with the mind of Christ, the believer walks as Christ walked..$^{50}$ Thus, Christian Perfection refers to a state of perfect love, righteousness and true holiness, which every believer may attain by being delivered from sin's dominion, by loving God with all the heart, soul, mind and strength, and by loving one's neighbor as one's self.

Wesley's concept of Christian holiness is foundational to Pentecostal theology. Anderson rightly avers that Wesley's "doctrine of entire sanctification and the possibility of spiritual experiences after conversion undoubtedly constituted the egg that hatched the Holiness movement and its offspring, Pentecostalism." ${ }^{51}$ Bruner says "it appears that out of the Methodist-holiness quest for [the] experience of sanctification, or a 'second work of grace' after justification, came Pentecostalism's centering of its aspiration in an instantaneously experienced baptism in the Holy Spirit after conversion." 52 As hinted earlier, Fletcher's thought about the reception of the Holy Spirit differed from Wesley's. Unlike Wesley who taught that the Spirit is received at conversion, Fletcher taught that the reception of the Spirit was after conversion..$^{53}$ Fletcher's new interpretation caused much concern and frequent rejection by many within the Holiness movement because the Holiness advocates had always associated the second blessing, of sanctification (holiness) with a baptism by the Holy Ghost and considered both to be aspects of the same experience. Fletcher's position began to spread and eventually became key in the Pentecostal tradition.

Accordingly, Wesley's emphasis on sanctification after conversion was replaced by a Pentecostal emphasis on baptism in the Holy Spirit and the speaking in tongues. The reception of the Holy Spirit subsequent to salvation became

${ }_{44}$ J. K. Asamoah-Gyadu, Contemporary Pentecostal Christianity: Interpretations from an African Perspective (Oxford: Regnum Books International, 2013 ), 162. Italics original.

45 Asamoah-Gyadu, Contemporary Pentecostal Christianity, 162.

46 Charles Yrigoyen Jr., John Wesley: Holiness of Heart and Life (New York: The Mission Education and Cultivation Program Department for the Women's Division, 1996), 24.

47 Ibid., 25.

48 Ibid.

49 Ibid.

50 Yrigoyen Jr., John Wesley, 26.

51 Anderson, Introduction to Pentecostalism, 26.

52 Bruner, A Theology of the Holy Spirit, 37.

53 Anderson, Introduction to Pentecostalism, 26; Lawless, God's Peculiar People, 28-29. 
an important part of Fletcher's tradition and subsequently an important aspect of Pentecostalism. It is in this light that Bruner asserts that "In Pentecostalism, the theological focus is shifted almost entirely from Wesley's goal of final salvation and the sanctification which will achieve it to the baptism in the Holy Spirit and the glossolalia which will assure it. In Pentecostalism the desire for the baptism in the Holy Spirit sweeps every other doctrine into its vortex including the doctrine of sanctification." ${ }^{4}$ The major influence, of Wesleyanism on Pentecostalism in this regard, therefore "has been the centering of spiritual desire on experience and especially on an experience subsequent to conversion, to be instantaneously engaged, and hence of most consequence, requiring the meeting of certain conditions beyond conversion or justifying faith for its attainment." ${ }^{55}$

Like Methodists, Pentecostals believe that the ability to live a holy life comes through spiritual renewal. Asamoah-Gyadu quotes Muhlen as saying that "renewal of the Spirit is the renewal of our human spirit effected in us by the Holy Spirit: the renewal of our feeling, willing, thinking, of our whole person." ${ }^{56}$ Therefore, after one's conversion, the old self must die and the person should put on a new self, renewed and energized to overcome sin and temptation. The victorious Christian life does not however come by chance. One needs to be discipled through effective teaching. Compromises are not entertained in Christianity in general, particularly so in Pentecostal Christianity. The Church of Pentecost "is noted for its uncompromising holiness ethic and high moral standards." ${ }^{57}$ Cooperate prayers where people have the opportunity to ask God for forgiveness of sin and for God's empowerment to overcome the struggles of life has been part of Pentecostal Christianity since its inception. This makes personal testimonies about the personal transformation from a worldly life to life in Christ very significant in Pentecostal services. The Church of Pentecost has specific sanctions for members who visit questionable locations (like the shrine), indulging in pre-marital and extramarital sex, and alcoholism. ${ }^{58}$

The outward or external dimension of Christian holiness has to do with the believer's relationship with other humans and the environment. For Wesley, Christianity is a social religion and therefore one's relationship with God must have a direct impact on his or her relationship with other humans and the environment. For the outward holiness to be demonstrated in one's life he or she must avoid unholy thoughts and acts like "envy, hasty judgment, pride, anger, injustice, greed, quarreling, intemperance, and neglecting other people's need" and rather cultivate holy habits such as "patience, kindness, generosity, forgiveness, justice, self-denial, sacrifice, and desiring the best for [one's] neighbors." ${ }^{9}$

Wesley warned against the dangers of riches and to set an example, he engaged in a wide range of social ministries. Wesley taught that God expect the wealthy in the society to give away their excess wealth. He believed that Christian giving should be governed by the principle of equality so that "The one who gathered much did not have too much, and the one who gathered little did not have too little" (1 Cor. 9:12-15). He charged the rich: "Be ye ready to distribute to everyone according to necessity." ${ }^{60}$ Though such a step will not make all equally wealthy, it will help sustain the poor. Wesley shifts attention from wealth accumulation to wealth distribution that ensures that the needs of others are met. Not only does this principle help us to store up treasures in heaven, it also helps us to overcome the intoxicating nature of wealth.

Wesley's social ethic or external holiness is seen in the social concerns of Pentecostals. Most Pentecostal churches have contributed to the socio-economic development of their societies through the provision of amenities such as micro-finance companies, lodging facilities, portable drinking water, and road networks. ${ }^{6}$ Some Pentecostal churches seek foreign aid from donors to fund some of the developmental projects they undertake. ${ }^{62}$ Some Pentecostal churches teach their members how to start their own businesses and also give them some capital (in the form of a loan or a gift) to establish their businesses. ${ }^{63}$ Some Pentecostal churches also have a scholarship scheme as part of their social responsibilities. Pastor Mensah Otabil of the International Central Gospel Church is said to have instituted a nondiscriminatory scholarship scheme for gifted but needy students in Secondary, Technical and Vocational institutions. ${ }^{64}$ All these measures contribute immensely to national development in a way that resonates with Wesley's social ethics.

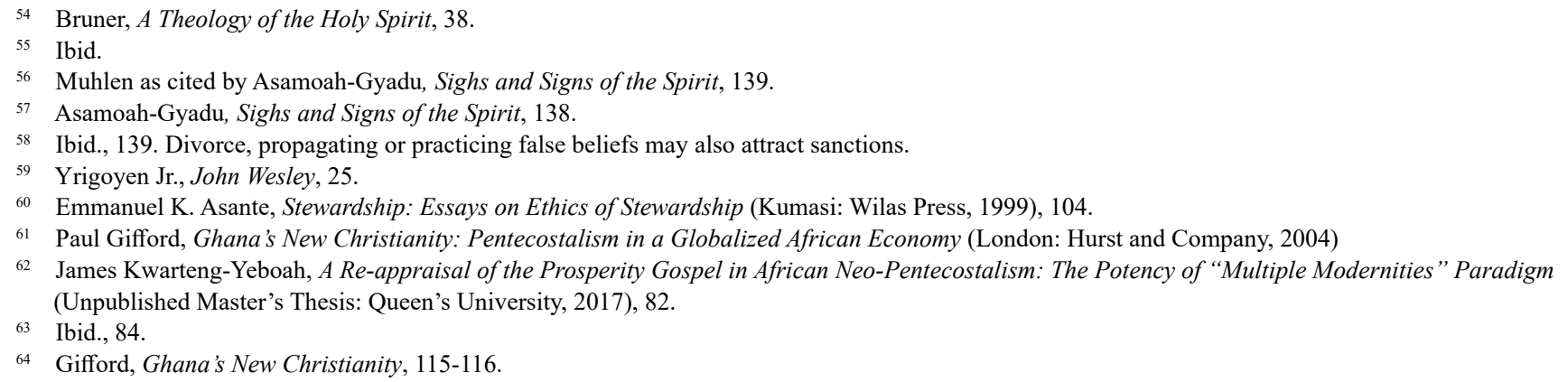




\section{Emphasis on Charismata}

Wesley laid great emphasis on charismata. In his notes on 1 Corinthians 12 , he notes that God pours his gifts abundantly in his church and so gifts are not learnt in contradistinction from the idle learning of Greek Philosophers ${ }^{65}$ His point is that anyone who is ready for these gifts and has true communion with God will have it. He goes further to state that the Corinthian church failed to use these gifts wisely. ${ }^{66} \mathrm{He}$ considered some gifts as ordinary and these include the gifts of music, preaching, teaching, service, wisdom (convincing speech), counseling and other "common gifts" bestowed on Christians. He remarks (with reference to 1 Pet. 4:10), "As everyone hath received a gift-Spiritual or temporal, ordinary or extraordinary (although the latter seems primarily intended)-so minister it to one another-employ it for the common good." ${ }^{67}$ Commenting on 1 Corinthians 12:8, Wesley describes the gift of wisdom as "a power of understanding and explaining the manifold wisdom of God in the grand scheme of gospel salvation" and the gift of knowledge as "an extraordinary ability to understand and explain the Old Testament types and prophecies". ${ }^{68}$

In his letter to Conyers Middleton, Wesley lists the various extraordinary gifts as including "casting out devils; speaking with new tongues; miracles (like escaping dangers, in which otherwise they must have perished); healing; prophecy (in the sense of foretelling); visions; divine dreams; and, discerning of spirits." ${ }^{69}$ Wesley considered these gifts as primarily meant for the conversion for both the individual who experiences it and the individuals who hear the testimony of this powerful experience. He does not consider the extraordinary gifts as the reserve of special people but for every believer who prays for it in accordance to God's will. He writes "I pretend to no extraordinary revelations and gifts of the Holy Ghost - none but what every Christian may receive and ought to expect and pray for."70

Wesley did not trust every spirit, though he never prohibited extraordinary revelations. He once wrote: "Trust not in visions and dreams; in sudden impressions, or strong impulse of any kind. Remember, it is not by these you are to know what is the will of God on any particular occasion; but by applying the plain scripture rule, with the help of experience and reason, and the ordinary assistance of the Spirit of God." ${ }^{\prime 1}$ He maintained that all personal revelations must be in strict accordance with Scriptures.

Wesley not only preached about the gift of healing, he experienced it himself. In his explanatory notes on Mark 16: 17, Wesley records one of his experiences at the town of Leonberg, where a crippled was healed through the preaching of this text. ${ }^{72} \mathrm{He}$ also wrote about his own healing from toothache which had been declared incurable by the most eminent physicians of his time, through prayers. ${ }^{73}$ Wesley's healing ministry was backed by holiness and prayer life because he knew that it was through prayer that he could move God to heal the sick. Knowing the power of prayer, "Wesley prayed as easily as he breathed." ${ }^{74}$ In addition to prayer, Wesley used medicine to help meet the needs of sick, people. ${ }^{75}$ Wesley is said to have experienced this supernatural healing gift in the early days of Methodist revival. Almost every sick person got healed when Wesley visited them and some even claimed that they were healed by the mere touching of his clothes. Concerning his healing ministry, Wesley wrote: "I visited several of the sick. Most of them were ill of the spotted fever; which, they informed me, had been extremely mortal; few persons recovering from it. But God had said: 'Hitherto shalt thou come.' I believe there was not one with whom we were, but recovered."76

Wesley also used the power of the Holy Spirit to cast out evil spirits. Wesley set the biblical and theological stage for "casting out devils" when he wrote, "In order to have the clearest view of this, we should remember, that (according to the scriptural account) as God dwells and works in the children of light so the devil dwells and works in the children of darkness. As the Holy Spirit possesses the souls of good men, so the evil spirit possesses the souls of the wicked." 77 This means that it is important for one to invite the Holy Spirit to come and dwell in him or her as part of the process of being delivered from evil-spirit possession. According to Daniel Jennings there are no less than sixteen cases of demoniac possession recorded in the works of Wesley. ${ }^{78}$ Wesley admitted his fear when he confronted his first case of demon

\footnotetext{
John Wesley, Wesley's Notes on the Bible: The New Testament edited by Anthony Uyl (Ontario: Woodstock, 2017$), 198$.

Ibid.

Ibid., 300.

Ibid., 199.

9 Wesley cited by Dojcin Zivadinovic, "Wesley and Charisma: An Analysis of John Wesley's View of Spiritual Gifts” in Andrews University Seminary Student Journal Vol. 1, No. 2 (2015): 53-71, 61.

70 Wesley cited in Kenneth C. Kinghorn, Wesley: A Heart Transformed Can Change the World Study Guide (Abingdon: Nashville, 2011), np. https://books.google. com.gh/books?id=kh75SlbS35YC\&pg=PT34\&lpg=PT34\&dq

71 Stephen Westerholm and Martin Westerholm, Reading Sacred Scripture: Voices from the History of Biblical Interpretation (Grand Rapids, MI: Wm. B. Eerdmans Publishing, 2016), 295.

72 Wesley, Wesley's Notes on the Bible, 62.

73 Jeff Doles, Miracles and Manifestations of the Holy Spirit in the History of the Church (Seffner, FL: Walking Barefoot Ministries, 2008$), 204$.

74 R. Jeffrey Hiatt, "John Wesley \& Healing: Developing Wesleyan Missiology" The Asbury Theological Journal 59(1\&2) (2004): 89-109, 97.

75 Ibid., 96

76 Doles, Miracles and Manifestations, 200.

77 John Wesley, The Works of John Wesley: Development in Doctrine \& Theological System (Harrington, DE: Delmarva Publications, Inc, 2015), np. https://books. google.com.gh/books?id=W-t7CgAAQBAJ\&pg=PT511\&lpg=PT511\&dq

78 Daniel R. Jennings, The Supernatural Occurrences of John Wesley (Oklahoma City: Sean Multimedia, 2005), 8-37
} 
possession which occurred in the fall of 1739 at Bristol. He therefore prayed for the demon possessed at a distant and after some time, he had the news that the demon had left the young girl involved. His faith and courage in this exercise began to grow after this experience.

There is no record that Wesley himself ever spoke in tongues. Yet, Wesley believed that the gifts of speaking in tongues is a legitimate gift for the Church at any place and in any age. Concerning the absolute need of the Holy Spirit in the life of the believer, Wesley writes "The life of God in the soul of the believer ... implies the continual inspiration of God's Holy Spirit: God's breathing into the soul, and the soul's breathing back what it first receives from God; a continual action of God upon the soul...And hence we may infer the absolute necessity of this re-action of the soul (whatsoever it be called) in order to the continuance of the divine life therein."79

The Wesleyan teaching about Charismata became one of the cardinal teachings of Pentecostalism. Pentecostal Christianity is experiential rather than creedal. Like the first Wesleyans, Pentecostal worship is organized in such a way as to invoke the presence of the Holy Spirit. Consequently, Pentecostal worship is characterized by "its belief in the experience of the Holy Spirit and by the normalization of charismatic experience in religious practice." ${ }^{80}$ These experiences include "speaking in tongues, revelations, prophecies, healing, exorcism or deliverance", and other spiritual experiences that as considered as the consequence of the descent of the Holy Spirit upon the believer. ${ }^{81}$ These pneumatic phenomena were part of the formative period of the Pentecostal movement. In Africa, for example, where the pneumatic orientation of Pentecostalism resonates with the African primal religious experiences, Pentecostalism is highly patronized. Here, Pentecostal Christianity has responded very well to the religious, spiritual, heal and economic needs of its members. This makes Pentecostal churches more appealing and enjoyable to many people than the historic mission churches. The Church of Pentecost, for example, in keeping with the Pentecostal ethos, has a number of prayer and healing centers devoted to the ministries of prayer, healing and deliverance.

Wesley taught the importance of subjecting religious experiences to the scrutiny of Scriptures. Founding members of Pentecostalism applied this principle in their ministry and so experience was always measured against biblical standards. William Seymour is said to have written, "If we remain in the Scriptures and follow the blessed Holy Spirit all the way, we will be able to measure up to the Word of God in all its fullness." ${ }^{82}$ Initially some Pentecostals practised writing of tongues; but this was judged to be unscriptural and so it was discouraged. ${ }^{83}$

\section{CONCLUSION}

The study has established the influence of Wesleyanism on Pentecostalism from both the historical and theological/ practical perspectives.The paper does not suggest that everything Pentecostal is Wesleyan; rather, it contends that key Wesleyan elements that were adopted by Pentecostals form the Wesleyan Holiness movement making Pentecostal Christianity thrive. Further, the study does not in any way argue that everything about Pentecostal Christianity is worthemulating; contemporary Pentecostalism has its own shortfalls including over-emphasis on miracles, commercialization of the gospel, abuses in ministry, among others.

To ensure the survival of Christianity now and in the years to come, the study recommends the following. Firstly, contemporary Christianity should adhere to orthodox doctrines such as human sinfulness and need for salvation, justifying by faith alone, sanctification as implication of justification and its growth and assurance of salvation, among others. Secondly, contemporary Christianity must emphasize the need for people to have a personal encounter with God (that leads to a personal transformation) rather than an intellectual knowledge about God (2 Cor. 5:17). Thirdly, the Church must teach and demonstrate personal and social holiness. The Christian experience is not only personal but social as well; therefore, one's vertical relationship with God must inform his or her horizontal relationship with other humans and the environment. Holiness must be pursued in both private and public life. Fourthly, effective Bible study through small-group participation must be ensured. Discipleship programs must be organized in such a way as to meet the need of every member of the Church regardless of the person's level of spirituality. For example, there is the need to have a class for new converts who may not be ready for solid food so that they can have milk available for their consumption and growth. Fifthly, the Church must be radically evangelistic. Obviously, the Christian Church cannot survive for long if it depends solely on biological growth, that is, increase obtained when children are born into the church. Sixthly, there is the need for the church to provide, among others, the spiritual, economic, social, security, health needs of members. These provisions must however contribute to the salvation of the members from the penalty and dominion of sin. Finally, the church needs to show a high concern for the lay ministry, equipping every member to use the gifts given to him or her by the Spirit. By implementing these and other relevant strategies, the Christian church

\footnotetext{
79 David Martin Whitworth, Missio Dei and the Means of Grace: A Theology of Participation (Eugene, OR: Wipf\&Stock , 2019 ), 89.

${ }^{80}$ Asamoah-Gyadu, Contemporary Pentecostal Christianity, 17.

81 Ibid.

82 John Christopher Thomas (ed.), Toward a Pentecostal Eschatology (Dorset: Deo Publishing, 2012), 62.

83 Ibid.
} 
will not only survive but will also make meaningful impact in the life of its adherents, the glory will be God's and the blessings human's.

\section{BIBLIOGRAPHY}

Aboagye-Mensah, Robert. John Wesley and the Methodists. Accra: Asempa Publishers, 2013.

Asamoah-Gyadu, Johnson K. African Charismatics: Current Developments within Independent Indigenous Pentecostalism in Ghana. Leiden: Brill, 2005.

. Contemporary Pentecostal Christianity: Interpretations from an African Perspective. Oxford: Regnum Books International, 2013.

. Sighs and Signs of the Spirit. Oxford: Regnum Africa, 2015.

Asante, Emmanuel K. Stewardship: Essays on Ethics of Stewardship. Kumasi: Wilas Press, 1999.

Boafo, Paul K. John Wesley's Theology and Public Life: His Socio-Political Thought in the Ghanaian Context. Accra: Asempa Publishers, 2014.

Bruner, Frederick Dale. A Theology of the Holy Spirit: The Pentecostal Experience and the New Testament Witness. Eugene, OR: Wipf\&Stock, 1997.

Doles, Jeff. Miracles and Manifestations of the Holy Spirit in the History of the Church. Seffner, FL: Walking Bare foot Ministries, 2008.

Gifford, Paul. Ghana's New Christianity: Pentecostalism in a Globalized African Economy. London: Hurst and Company, 2004.

Greenfield, John. Power from on High: The 20th Anniversary of the Great Moravian Revival 1727-1927. Atlanta, GA: CTM Publishing, Inc., 2017.

Hammond, Geordan. John Wesley in America: Restoring Primitive Christianity. Oxford: Oxford University Press,2014.

Hiatt, R. Jeffrey. "John Wesley \& Healing: Developing Wesleyan Missiology" in The Asbury Theological Journal 59(1\&2) (2004): 89-109.

Hopper, Isaac. "Christ Alone for Salvation": The Role of Christ and His Work in John Wesley's Theology. PhD Thesis: The University of Manchester, 2017.

Jennings, Daniel R. The Supernatural Occurrences of John Wesley. Oklahoma City: Sean Multimedia, 2005.

Kinghorn, Kenneth C. Wesley: A Heart Transformed Can Change the World Study Guide (Abingdon: Nashville, 2011 https://books.google.com.gh/books?id=kh75SlbS35YC\&pg=PT34\&lpg=PT34\&dq

Kuzmic, Peter. "Pentecostals in the Evangelical Family: A Historical and Theological Reflection" in Together in One Mission: Pentecostal Cooperation in World Evangelization edited by Arto Hamalainen and Grant Mc Clung. Cleveland: Pathway Press, 2012.

Kwarteng-Yeboah, James. A Re-appraisal of the Prosperity Gospel in African Neo-Pentecostalism: The Potency of "Multiple Modernities" Paradigm. Unpublished Master's Thesis: Queen's University, 2017.

Lawless, Elaine J. God's Peculiar People: Women's Voices \& Folk Tradition in a Pentecostal Church. Kentucky: The University Press of Kentucky, 2005.

Menzies William W. and Menzies Robert P., Spirit and Power: Foundations of Pentecostal Experience. Grand Rapids, MI: Zondervan, 2000.

Omenyo, Cephas N. Pentecost Outside Pentecostalism. Zoetmeter: Boekencenbtrum Publishing House, 2002.

Robins, R. G. Pentecostalism in America. California: Praeger, 2010.

Synan, V. "Pentecostalism" in Evangelical Dictionary of Theology Second edition edited by Walter A. Elwell. Grand Rapids, MI: Baker Academic, 2001.

Thomas, John Christopher (ed.). Toward a Pentecostal Eschatology. Dorset: Deo Publishing, 2012.

Thorsen, Don. "Sola Scriptura and the Wesleyan Quadrilateral" in Wesleyan Theological Journal Volume 41, Number 2 (2006): 7-27.

Wesley, John and Charles Wesley, John and Charles Wesley: Selected Prayers, Hymns, Journal Notes, Sermons, Letters, and Treatises edited by Frank Whaling. New York: Paulist Press, 1981.

.The Works of John Wesley: Development in Doctrine \& Theological System Harrington, DE: Delmarva

Publications, Inc, 2015.https://books.google.com.gh/books?id=W-t7CgAAQBAJ\&pg=PT511\&lpg=PT511\&dq .Wesley's Notes on the Bible: The New Testament edited by Anthony Uyl. Ontario: Woodstock, 2017.

Westerholm, Stephen and Martin Westerholm, Reading Sacred Scripture: Voices from the History of Biblical Interpretation. Grand Rapids, MI: Wm. B. Eerdmans Publishing, 2016.

Whitworth, David Martin. Missio Dei and the Means of Grace: A Theology of Participation. Eugene, OR: Wipf \& Stock, 2019. 
Yrigoyen Jr., Charles. John Wesley: Holiness of Heart and Life. New York: The Mission Education and Cultivation Program Department for the Women's Division, 1996.

Zivadinovic, Dojcin. "Wesley and Charisma: An Analysis of John Wesley's View of Spiritual Gifts" in Andrews Uni versity Seminary Student Journal Vol. 1, No. 2 (2015): 53-71.

\section{ABOUT AUTHOR}

Isaac Boaheng, an ordained minister of the Methodist Church Ghana, currently serves as a Translator for the Bible Society of Ghana. Isaac holds a Master of Divinity degree from the Trinity Theological Seminary (Accra-Ghana) and has research interest in Public Theology, Biblical Studies, and African Christianity. 